\begin{tabular}{|l|l|l|l|l|l|}
\hline Paläont. Z. & 60 & $3 / 4$ & $12 \mathrm{Abb}$. & $255-275$ & Stuttgart, Dezember 1986 \\
\hline
\end{tabular}

\title{
The type species of the Ordovician trilobite Symphysurus: systematics, functional morphology and terrace ridges
}

\author{
R. A. FORTEY, London* \\ With 12 figures
}

Kurzfassung: Die Typusart der ordovizischen Trilobiten-Gattung Symphysurus, S. palpebrosus DaLMAN 1827, wird anhand des schwedischen Typusmaterials neu beschrieben. Die Gattung tritt, verglichen mit der damals meist engeren geographischen Bindung anderer Trilobiten, in auffallend weiter Verbreitung auf, nämlich sowohl in peripheren Bereichen des Skandinavischen Paläokontinents als auch des (heute südeuropäisch-vorderasiatischen) Gondwana-Nordsaums, und zwar in relativ bathyaler Fazies.

$S$. palpebrosus besitzt an enge Einrollung angepaßte Organisationsmerkmale. Die funktionsmorphologische Analyse zeigt, daß sich diese Art zeitweilig in bumastoider Stellung, also mit eingegrabenem Pygidium und Thorax, aber freiem Cephalon im Sediment aufhielt, der Nahrungssuche aber außerhalb ihres Baus nachgegangen sein dürfte. Die Funktion der auf manchen Partien der Cuticula wohl ausgebildeten Terrassenlinien ist noch immer ein in mancher Hinsicht offenes Problem. Ihre Stellung, Lage und Anordnung zeigen, daß nur einige davon mit dem Eingraben in das Sediment zu tun hatten. Soweit sie mit petaloiden Thoraxfacetten gekoppelt sind, könnten sie die im eingerollten Zustand herabgesetzte Atmung gewährleistet haben.

Abstract: The type of the widespread Ordovician trilobite Symphysurus, S. palpebrosus Dalman, 1827 , is redescribed from the type Swedish material; its distribution is documented. Symphysurus is one of very few trilobite genera to be found in both Ordovician Baltica and Gondwana, in more peripheral sites relative to the platform areas. S. palpebrosus has complex coaptative devices to ensure tight enrollment. Analysis of the functional morphology shows that it spent at least part of its life with thorax and pygidium buried in the sediment in the bumastoid stance, although it may have fed outside its burrow. Terrace ridges are well developed on certain parts of the cuticle; their positioning and geometry shows that only a few of them could have functioned in direct engagement with the sediment. Those associated with petaloid thoracic facets may have permitted respiration in the enrolied condition.

\section{Introduction}

The type species of the nileid trilobite genus Symphysurus is $S$. palpebrosus DaLmaN, 1827, one of the commoner Scandinavian Ordovician trilobites. Curiously, this species has never been given a modern description, in spite of the fact that Symphysurus has been widely reported elsewhere in the world. The illustration used in the Treatise on Invertebrate Paleontology (C. Poulsen in: MoOre 1959) was adapted from that given in ANgelin (1851), and the only photographic illustration of the species from Scandinavia is a cephalon from Geschiebe material illustrated by NeBEN \& KRUEGER (1971: Plate 5, fig. 5, 6). It is apparent that a detailed appraisal of this oft-quoted trilobite is overdue, especially as the Treatise is now due for revision. The purpose of this paper is to describe the morphology of S. palpebrosus, to out-

"Address of the author: R. A. FoRTEY, British Museum (Natural History), Cromwell Road, London SW7, 5BD, England. 
line the distribution of the species in Scandinavia, and to discuss its probable life habits. S. palpebrosus is also a particularly informative trilobite for a consideration of the possible functions of cuticular terrace ridges. I thank VALDAR JAANUSSON for advice and encouragement in this project, AdRIAN Rushton for reading the manuscript, Dick JefFERIES, JOHN TAYLOR, Keith Harrison for discussion, David Bruton for advice on Oslo specimens, and Peter YORK and CEDRIC CHUTE for technical help.

\section{Systematic discussion \\ Family Nileidae ANGELIN, 1854 \\ Genus Symphysurus GoldFuss, 1843}

Type species: Asaphus palpebrosus Dalman, 1827, designated Barrande 1852.

Diagnosis: Nileid trilobites with seven or eight thoracic segments; axial furrows welldefined on cephalon and thorax; glabella parallel sided or slightly forward-expanding, convex (tr.), often with sculpture of terrace ridges; eyes large; genal spines lacking; pygidium subsemicircular, lacking distinct border; pygidial axis at least partially defined dorsally, and clearly visible on internal moulds, long (sag.) compared with that of Nileus; inner margin of pygidial doublure approximately parallel to pygidial margin.

Rem arks: Symphysurus is distinguished from Nileus by its clearly defined and convex (tr.) glabella, and by its relatively long pygidial axis; the outline of the pygidial doublure is different - on Nileus the doublure is even wider, and its inner margin is convex-forwards on either side of the pygidial axis.

\section{Symphysurus palpebrosus (DALMAN, 1827)}

Figs. 1, 2, 5, 10

1827. Asaphus palpebrosus; Dalman: 245, Pl. 4, figs 2 a-e

1837. Asaphus palpebrosus; Hisinger: 15 , Pl. 3, fig. 1

?1838. Trilobites laevis; BOECK: 142 (? pars)

1843. C. (sic) palpebrosus; GoldFuss: 553

1843. Asaphus palpebrosus; BURMEISTER: 124

1846. Symphysurus palpebrosus; BURMEISTER: 107

1852. Symphysurus palpebrosus; BARRANDE: 651 (type species indicated)

1852. Nileus palpebrosus; ANGELIN: 18 , Pl. 16 , fig. $4 \mathrm{a}, \mathrm{b}$

1854. Symphysurus palpebrosus; ANGELIN: 60

1882. Symphysurus palpebrosus; BRøGGER: 61

1901. Symphysurus palpebrosus; LINDSTRÓM: Pl. 5, fig. 18

1942. Symphysurus palpebrosus; LAKE: 314 , text-fig. $5 \mathrm{a}$

1966. Symphysurus palpebrosus; POULSEN: 126 (listed)

1968. Symphysurus palpebrosus; BEDNARCZYK: Pl. 1, figs. 1, 3

1969. Symphysurus palpebrosus; MODLINSKI \& POKORSKI: PI. 1, figs 1,3

1971. Symphysurus palpebrosus; NEBEN \& KRUEGER: Pl. 5, figs 5, 6

1972. Symphysurus palpebrosus; JoHANsson et al.: 579 (listed)

1973. Symphysurus palpebrosus; MODLINSKI: 52, pl. 3, figs 7, 8

1976. Symphysurus palpebrosus; CoUR TEssole \& Pillet: Fig. 2D.

Fig. 1. Symphysurus palpebrosus (DALMAN, 1827), $\times 2$, Expansus Limestone, Sweden. A, B, enrolled example, original of DALMAN, 1827, and chosen here as lectotype, lateral view and anterior view, Östergötland, Ar 17066. C, enrolled specimen with well-preserved cephalic cuticle in palpebral view, Östergötland, Västanå, Ar 17081. D, E, partially unenrolled specimen in lateral view, and with pygidium in dorsal view to show lack of terrace ridges on pygidium and thorax, Ostergötland, Västană F, pygidial doublure, $\times 2$, PMO 2015, Grundvik, Roken, Oslo. 

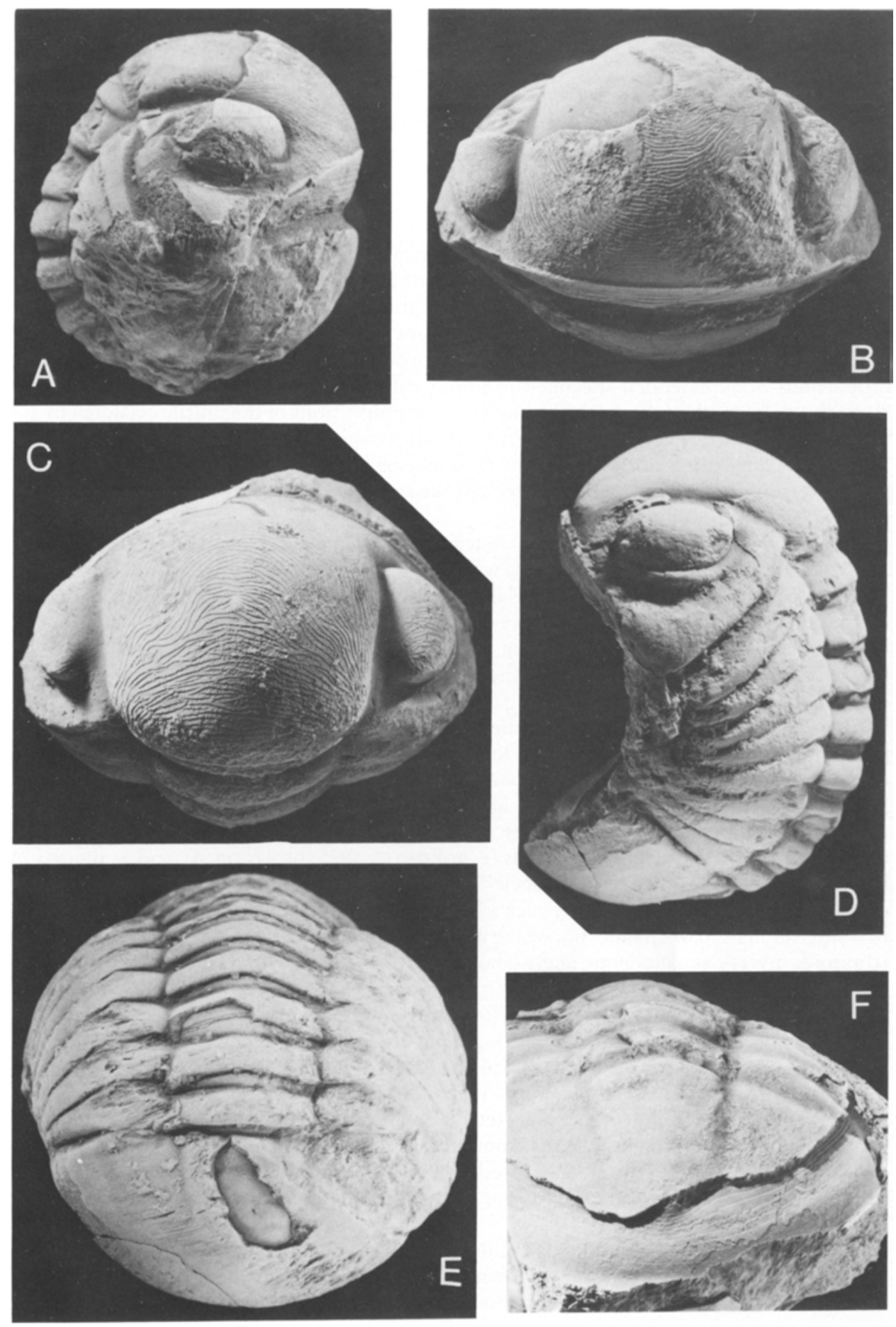
Lec to type: RMS Ar 17066. Original of Dalman 1827, plate 4, figs. 2a-e. Dalmans original collection in the Naturhistoriska Riksmuseet, Stockholm includes numerous specimens from Östergötland, some or all of which are presumably syntypes. However, only one of these shows exactly the same degree of enrollment as shown on the original figure of DALMAN (see Fig. 1A), and it is possible to be confident that this specimen was the one used by DaLman to illustrate the species. Moreover, it is one of the best specimens, retaining much of the cephalic cuticle, which also suggests that it was likely to have been originally chosen by DALMAN for illustration. It is selected here as lectotype. Locality, probably Västanå, Östergötland. Expansus Limestone.

Other occurrences: Collections in the Riksmuseet, Stockholm, from "Expansuskalk". Östergötland: Västanå (= Husbyfjöl of older authors); Kungs Norrby; Flistad; Ljungsbro; Öland: Mellan Sandvik o. Stenninge; Resmo; Borgholm and Borgholms Slott; Närke: Lanna; Yxhult and Latorp; Bornholm: Komstad Limestone.

Description: All available specimens are more or less enrolled and it is difficult to assess proportions of an extended specimen in life orientation (see below). By stretching cotton along the mid-length of the dorsal exoskeleton the proportions of the profile occupied by the cephalon, thorax and pygidium can be estimated, this being $33 \%, 40 \%$ and $27 \%$ respectively. Transverse convexity is considerable, the axial lobe being broadly arched, adaxial parts of the pleural regions horizontal, while the free cheeks and lateral parts of the pleurae are steeply inclined downwards. Cuticle thick.

Cephalic length/width ratios based on ten well-preserved specimens range between 0.58 and 0.67 with an average of 0.63 . Glabella with transverse width at mid-length equal to sagittal length in palpebral view. Convex (tr.) glabella expands in width gently forwards to cranidial margin, axial furrows becoming shallower in front of eyes. No glabellar furrows defined. Glabellar tubercle, which is at, or slightly in front of sagittal mid-length in palpebral view, is in fact only developed as a "tubercle" on the internal mould, its dorsal expression (see Fig. 1C) being a smooth area - i. e. it is a thinning of the cuticle in the position described by FORTEY \& CLARKSON (1976) in the related genus Nileus at about the mid-length of the eyes, and probably functioning as a median eye. Palpebral lobes without rims, approaching axial furrows anteriorly and a little further removed from the glabella posteriorly, nearly horizontal. Total length of eye (exsag.) slightly less than half cephalic length in palpebral view. No specimen that I have seen preserves the eye lenses: they were presumably both exceedingly numerous and minute, as they are on other nileids (e. g. FORTEY 1975: pl. 17, fig. 4), and as figured by LINDSTRŌM (1901). Subocular eye "socle" separating visual surface from cheek is inflated, deepest medially. Most nileids have such a "socle", but on other genera it is not inflated. Narrow anterior marginal cephalic rim, which is not continued on lateral parts of free cheeks. Facial sutures diverge at a moderate angle (about $60^{\circ}$ to sag. line) behind eyes, curving a litle abaxially posteriorly to cut the posterior margin at an acute angle, and so defining short, triangular postocular fixed cheeks. Anterior sections of facial sutures diverge slightly in front of eyes before curving adaxially to run along cephalic margin inside rim to meet mesially. Free cheek in plan view about two-thirds as wide (tr.) as long (exsag.), with broadly rounded genal angle, to which posterior genal margin curves forwards. Doublure yokes cheeks together, lacking median suture, and is inclined steeply downwards, so that in profile (Fig. 1A, D) it continues the downward curve of the front of the glabella, interrupted only by the marginal rim, but curving horizontally at its inner edge. Doublure cut by deep vincular notch (Fig. 5D) running obliquely across it, abaxial to which the doublure is recurved closely beneath the free cheek (see Fig. 5A).

Hypostoma attached at inner edge of doublure and orientated parallel to palpebral lobes on dorsal surface, i. e. not continuing downward curve of doublure. Length (sag.) about twothirds maximum width (tr. excluding anterior wings) which is near anterior edge of lateral 

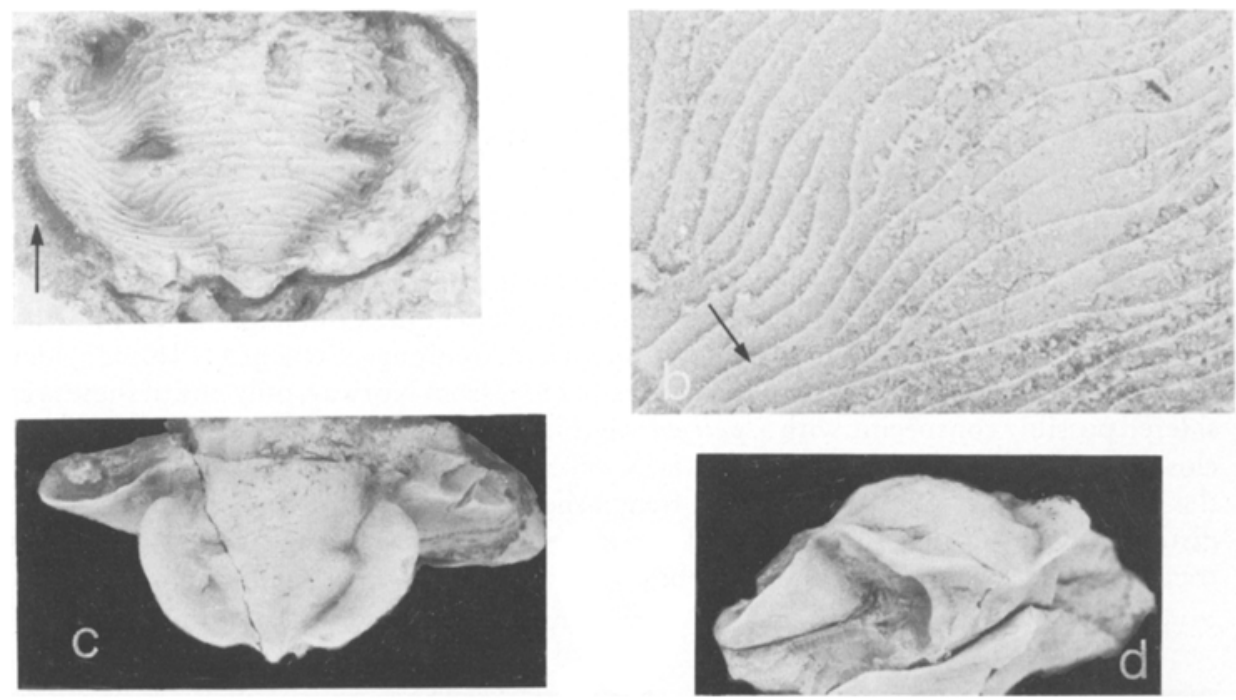

Fig. 2. Symphysurus palpebrosus (DALMAN, 1827), Expansus Limestone, Sweden. a, hypostome retaining cuticle showing strong terrace ridges; arrow points anteriorly $\times 4$, Östergötland, Västanå, Ar 17078. b, detail of Fig. 1c, $\times 8$, showing dorsal cephalic terrace ridges arrow; points anteriorly; note opposite facing direction to Fig. 2a. c, d, hypostome lacking cuticle, $\times 2.5$, ventral, and oblique views, showing wings and doublure, Ar 17035, Västanå.

borders. Middle body rather ill-defined, tapering posteriorly, with prominent pair of laterally placed, forward facing, smooth maculae at mid-length. Broad lateral borders slope inwards towards middle body, with rounded posterior extremities; small posteromedian spine, so that the posterior hypostomal margin is tripartite. Anterior wings extremely long and steeply downsloping (Fig. 2C), buttressed against the anterolateral parts of the cephalic doublure. On dorsal side of the lateral borders there is a pair of apodemes near their posterior margins.

Thorax with eight segments, well-defined axis gently tapering backwards to about threequarters anterior width at eighth segment. Half rings prominent, slightly wider (sag.) on anterior segments. Anterior articulation close to axial furrow, becoming further removed therefrom backwards; transverse width of facets correspondingly decreases backwards, the most anterior being steeply downsloping and occupying much of the pleural width (exsag.). Pleural furrows faint on dorsal surface, nearer anterior than posterior margin of segment, weak near the axis and fading altogether shortly outside the point of articulation. On internal moulds they are longer and deeper, and occupy more of the pleural width. Thoracic doublure broad (see Fig. 5E).

Pygidium subsemicircular, lacking border. Axis poorly defined on dorsal surface, continuing backward taper of thorax to ill-defined broadly rounded tip at about three-quarters pygidial length. The axis is much more clearly defined on internal moulds, and it is presumably on material of this kind that the reconstruction given in the Treatise (MOORE 1959: fig. 267.8) is based. Internal moulds also show up to three axial rings of which only the first is usually defined over the mid-part of the axis. Downturned facets occupy about half the pleural width. Wide doublure recurved close to dorsal exoskeleton, inner margin subparallel to pygidial edge, excavated around tip of axis, carrying articulating boss (Fig. 5C) at anterolateral edge. 
Surface sculpture is discussed in more detail below. Terrace ridges are strongly developed on the glabella, where the steep slopes face backwards; the strongest ridges of all are on the cephalic doublure, where they face upwards. Palpebral lobes also carry such ridges, which are feebly developed if at all on the free cheek, which is also finely pitted, Terrace ridges may be present on the axial rings of the thoracic segments, but are absent from the pleurae, and the dorsal surface of the pygidium. Fine scattered pits are present on surfaces from which terrace ridges are absent.

Re marks: S. palpebrosus occurs also in Poland (MODLINSKI 1973). BRøGGER $(1882: 21,61)$ reported S. palpebrosus in the Megistaspis Limestone (3ca) of the Oslo Region, Norway, that is in the lower third of the Orthoceras Limestone, of late Arenig age. STøRMER (1940: 115) identified three syntypes of Symphysurus laevis (BOECK 1838) from Norway; only one of these is considered possibly conspecific with S. palpebrosus (Fig. 3A). The others, however, resemble more closely a related species from Scandinavia, $S$. dorsatus PoulSEN from the Skelbro Member of the Komstad Limestone on Bornholm, fram a slightly older stratigraphic position, which is distinguished by having a longer and vaulted glabella, such that the sagittal length exceeds the transverse width at mid-length in palpebral view. The small collection in the Paleontological
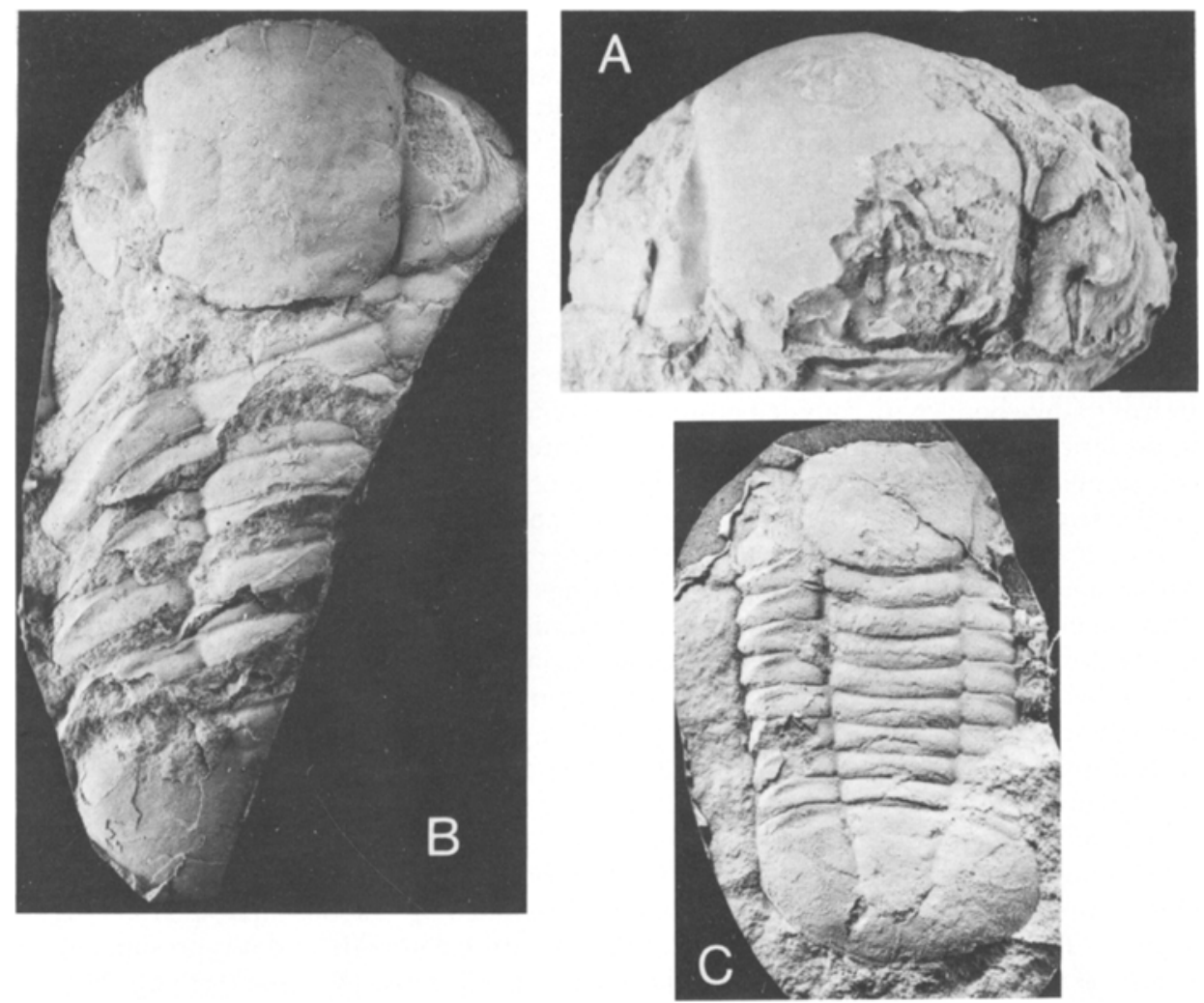

Fig. 3. Other Symphysurus occurrences. A, ?S. palpebrosus, $\times 2$, from "Bergersenslokka", Oslo, Norway. According to STøRMER this is one of three syntypes of Trilobites laevis BOECK, and it is the only one of these close to S. palpebrosus. PMO 56209. B, C, Symphysurus pater HoLUB, $\times 1$, casts of two specimens from the Arenig Klabava Formation, Bohemia, in collections of Rockycany Museum. 
Museum, Oslo, shows that true S. palpebrosus occurs inthe Megistaspis Shale (3c $\beta$ ) (e. g. PMO 1943), while it is possible that some of those recorded as $S$. palpebrosus from $3 \mathrm{c} \alpha$ might be better referred to $S$. dorsatus. The older (uppermost Tremadoc to earliest Arenig) species from Norway and Sweden S. angustatus SARS \& BOECK (see TJERNVIK 1956: pl. 2, figs 24, 25) also has a relatively long glabella, and one which hardly expands in transverse width forwards. This species is also described from the Montagne Noire, France (Courtessole \& Pillet 1975). $S$. arcticus FORTEY 1975 from the Arenig of Spitsbergen has only seven thoracic segments, but since species with seven or eight thoracic segments are also known in the other nileid genera Nileus and Platypeltoides, this difference in not regarded as of more than specific significance. Symphysurus pater (Holub 1911) is from the upper Arenig Klabava Formation of Bohemia; specimens (Fig. 3) are flattened in shale and hence somewhat difficult to compare directly with $S$. palpebrosus. In cephalic proportions this species appears to be identical with $S$. dorsatus POULSEN, while the glabellar sculpture is on a finer scale than in $S$. palpebrosus. S. pannuceus DEAN 1973 from the upper Arenig of Turkey is mostly known from internal moulds, which makes detailed comparison with $S$. palpebrosus difficult; however its glabella is more convex (tr.), expands less markedly forwards, and is proportionately longer, like that of $S$. dorsatus. S. blumenthali DEAN 1971, another Arenig species from Turkey, has a parallel sided glabella like the stratigraphically earliest species from Scandinavia and France. Several species of Symphysurus have been described from China. These include five from the Chi-lien Mountains, Northwest China (CHANG \& FAN 1960); the relatively smaller palpebral lobes and medially constricted glabellar form of these are suggestive of the genus Poronileus FORTEY 1975 rather than Symphysurus. However, two species described in detail by LU (1975) from Shensi, S. carinatus and $S$. subquadratus, are without doubt true Symphysurus species, most similar to $S$. angustatus of European species. Three species of Symphysurus have been recorded from the Tremadoc of Kazakhstan (LISOGOR 1961; BALASHOVA 1961), from rather poor material; they are generally similar to the Scandinavian Tremadoc species.

Taken together, these species comprise a morphologically coherent group, with relatively minor differences in proportions, surface sculpture and glabella shape indicating specific differences. Symphysurus is a soundly based, monophyletic genus of wide distribution in the earlier Ordovician.

\section{Distribution of the genus}

Symphysurus is an exceptionally widely distributed genus in the earlier Ordovician, a time when provinciality of trilobite faunas was at a maximum. It is one of very few genera to be found both in Ordovician Baltica and in France which (COCKS \& FORTEY 1982) were separated at the time by Tornquist's Sea, placing Baltica at temperate to warm-temperate palaeolatitudes, while the northern fringe of Gondwana (including southern Europe) lay at comparatively high palaeolatitudes. Furthermore, the occurrence of the genus in Spitsbergen - part of Ordovician Laurentia at near-equatorial palaeolatitudes - indicates an exceptional freedom from the palaeogeographical constraints which controlled the distribution of most trilobites at this time. However, Symphysurus is not found in typical platform successions in Ordovician Gondwana, being absent, for example, in the faunas described in detail by HENRY (1980) from Armorica, as it is from Iberia. It is found in comparatively deep water, argillaceous biofacies in the Montagne Noire, in association with cyclopygids, a trilobite family usually found in more peripheral-platform biofacies (e. g. FORTEY \& OWENS 1987). Bohemia and Turkey are other "Gondwanan" stations of the genus, and both also lay at the edge of the Gondwanan platform. In Spitsbergen (FORTEY 1975) Symphysurus also occurs in a comparatively deep water biofacies, which I termed the nileid community from the abundance of the eponymous family, and where it occurs with some other widespread genera, such as Shumardia and Nileus. The 


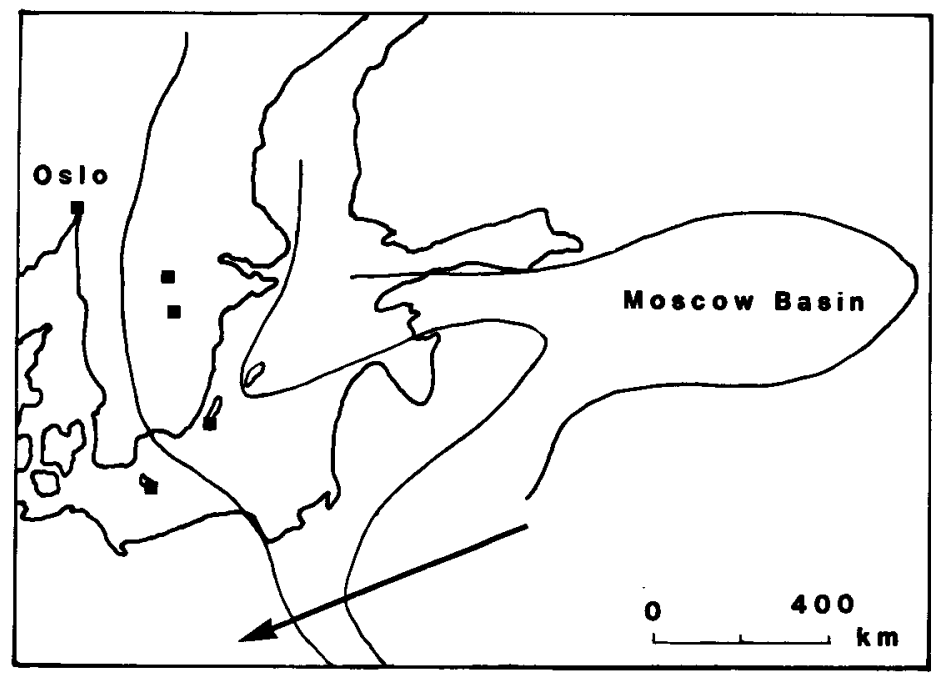

Fig. 4. Distribution of S. palpebrosus (DALMAN) in Scandinavia. Lines mark boundaries between the major "confacies belts" recognised by JAANUSSON \& BERGSTRÖM 1980, arrow shows direction of the on-shelf to off-shelf profile, showing how S. palpebrosus is found in more exterior sites. Each square represent several nearby localities. For explanation see text.

occurrence of S. palpebrosus in Scandinavia (Fig. 4) also shows that it occupied relatively exterior sites on the Baltic palaeocontinent, embracing the Oslo region, Scania and Bornholm, compared with the biofacies distribution over the platform as a whole (e. g. JAANUSSON \& BERGSTROM 1980). Trilobite faunas from such exterior sites are often relatively independent of former continent distribution; in fact some genera may be almost pandemic while contemporaneous and adjacent platform faunas are palaeogeographically restricted (FORTEY \& OWENS 1978: fig. 7). In view of its relationship to the peripheral areas of former continents, the most reasonable explanation for the widespread distribution of Symphysurus, is that it was a component of a relatively peripheral biofacies, like the nileid biofacies in Spitsbergen, which found suitable substrates on the edges of quite widely separated shelves in the earlier Ordovician.

\section{Aspects of functional morphology}

\subsection{Coaptative structures}

Coaptative structures are developed on the peripheral parts of the trilobite exoskeleton and function to interlock during enrollment. They have recently been closely studied (see HAMMANN 1985 and HENRY 1985 for excellent discussion and references) as they appear to be stable within a species, yet subject to progressive and adaptive changes through time. As HAMMANN noted, coaptative devices are one of the few morphological features of trilobites of which the function is unequivocal.

Symphysurus palpebrosus has a well-developed vincular furrow on the cephalic doublure (Figs 5D, G); the same structure was observed on S. pannuceus by DEAN (1973) but I have not proved it on other species of the genus. The furrow serves to receive the boss on the anterola- 

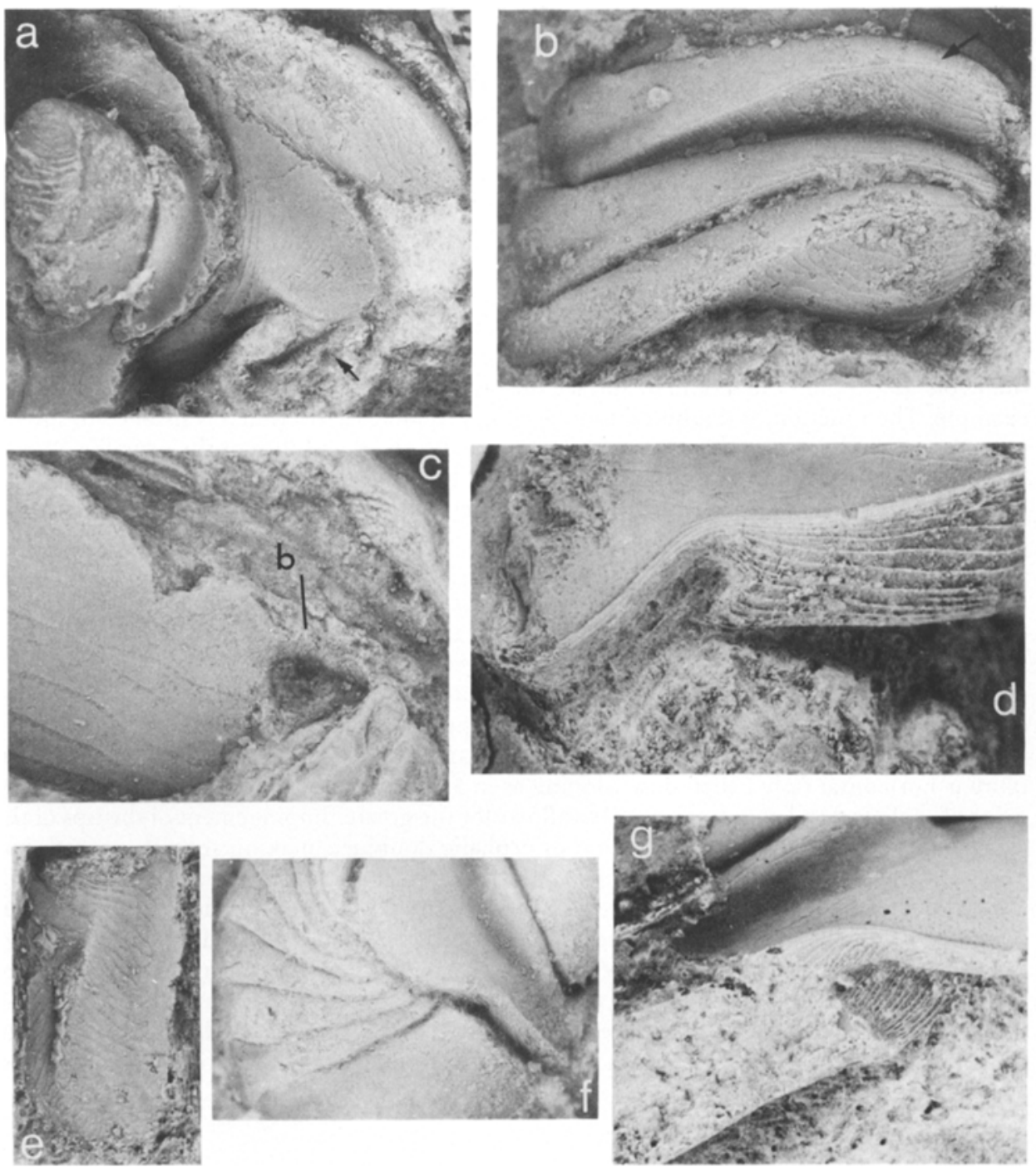

Fig. 5. Coaptative structures in S. palpebrosus, specimens from Expansus Limestone. a, dorsal surface of first thoracic segment, and external mould of ventral surface of the librigenal doublure, showing perfect correspondence between the thoracic facet and the posterior part of the cheek doublure; arrow points to small vincular grooves which receive pleural tips during enrollment, $\times 4$, BM I 5686. b, petaloid facets of thoracic segments; note terrace ridges; arrow points to transverse ridges which alone are not concealed during enrollment, as shown by middle segment, $\times 4$, old. coll. BM, not localised. c, detail from lectotype, Fig. $1 \mathrm{a}, \times 10$ showing pygidial doublure with external mould of boss (marked b) which fits into cephalic vincular groove. $\mathrm{d}$, g, cephalic vincular grooves, $\times 6$, on Ar 49474, from Mellan Sandvik o. Stenninge, Öland; d shows external face of groove on right side of cephalon in anterior view, and cephalic doublure showing strong upward-facing terrace ridges; $g$ is photographed into the groove on left side in anteroventral view showing its lining of fine terrace ridges. e, same specimen, external mould of doublure of seventh thoracic segment, $\times 5$, showing transverse vincular ridge, and distribution of terrace ridges. $f$, completely enrolled specimen showing telescoped pleural tips and pygidal margin, $\times 3$, Ar 17085, Västanå. 
teral margin of the pygidium and the pygidial facet; three small grooves on the doublure of the free cheek at the inner end of the vincular furrow (Fig. 5A) accomodated the tips of thoracic segments. Once enrolled, the trilobite is securely locked in by this device, which prevents lateral displacement between cephalon and pygidium. Note also that in the enrolled position the down-curved cephalic doublure engages closely with the recurved pygidial doublure so that almost the entire marginal areas are in close coaptation.

Terrace ridges continue into the vincular furrow (Fig. 5G), and they are also present on the opposing doublures. In enrolled position abutting parallel sets of terrace ridges on the cephalic and pygidial doublures will increase frictional resistance to movement, whether this is sliding between cephalic and pygidial margins, or any twisting motion produced by the attentions of a predator. Indeed, it is difficult to explain their presence along the sides and bottom of the vincular notch in any other way than as a coaptative feature - certainly in this position their role in gripping the sediment surface during burrowing must have been negligible, for example. The function of doublural terrace ridges to increase frictional resistance to movement in enrolled position does not, of course, rule out the possibility of their having a quite different function during the normal, un-enrolled life of the animal.

The facet of the first thoracic segment fits perfectly beneath the doublure of the free cheek, as shown by Fig. $5 \mathrm{~A}$; its further forward movement is prevented by abutting against the lateral extremity of the convex cephalic doublure.

Vincular furrows on other nileids have been described by SCHRANK (1972), FORTEY (1975) and HAN (1984). In particular, HAN has given a detailed account of coaptation in Nileus, illustrating a complex array of discrete grooves in the cephalic doublure for the reception of the tips of the thoracic segments as well as the anterolateral angle of the pygidium. Nileus is a less convex (sag.) trilobite than Symphysurus, and during enrollment the cephalon and pygidium meet one another at a lower angle (e. g. WHITTINGTON 1965: Pl. 30, fig. 9); the cephalic doublure is horizontal rather than downsloping as in S. palpebrosus. The lower angle of engagement of cephalon and pygidium in Nileus allows for the greater impingement of the tips of the thoracic segments over a longer section of cephalic doublure, making several separate pits necessary for close coaptation. In Symphysurus the vincular furrow is deeper than in other nileids, and cuts the cephalic margin, because of the nearly edge-wise approach of cephalic doublure and pygidial margin, and because it has to receive the boss developed on the lateral edge of the pygidial doublure. The primitive nileid arrangement may have been like that I figured on Poronileus (FORTEY 1975: pl. 41, fig. 6) with a simple L-shaped groove on the librigenal doublure. As has been described with other trilobites (e. g. Placoparia see HENRY 1985) the evolutionary history of the nileids includes the development of closer coaptation with the appearance of complex and sophisticated locking devices.

\section{Terrace ridges on thoracic pleurae}

Because the function of these coaptative devices is unequivocal, and their full development testifies to their importance in the biology of the trilobite, it is reasonable to discuss the function of finer, associated structures like terrace ridges from the point of view of their function in enrollment. The cephalic ridges have already been mentioned. However, terrace ridges are also well developed on the facets of the thoracic segments (Fig. 5B). Such terrace ridges are concentrated on these facets and do not extend on to the open pleural surface, that is, they are positioned only in those areas involved in enrollment. Hence it is not unreasonable to assert that they, like the terrace ridges on the cephalic doublure, must have had a function intimately connected with enrollment. The facets slid beneath the doublure of the preceding segment as far as the transverse ridge shown on Fig. 5E. The terrace ridges on the thoracic pleural facets have a characteristic oblique arrangement with steep slopes facing posterolaterally, which 


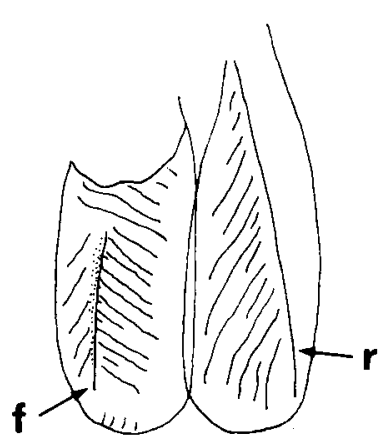

a

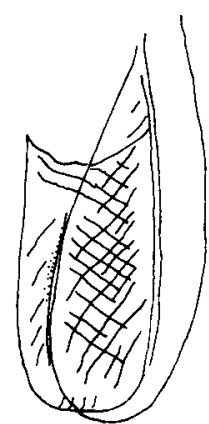

b

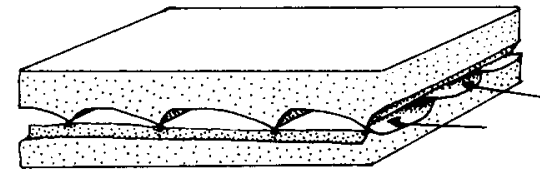

C

Fig. 6. Relationships of petaloid thoracic facets and doublure of thoracic segment in front under which the facet slides during enrollment. a, extended condition showing orientation of terrace ridges; $b$, upon enrollment two sets of terrace ridges have a criss-cross orientation; $c$, diagrammatic section through adpressed facet and doublure, showing how criss-cross relationships of terrace ridges allows ingress of irrigating water along small channels (arrows). $\mathrm{f}$ - vincular furrow stopping forward movement of facet $\mathrm{r}$ tranverse ridge at top of facet positioned to monitor completion of enrollment.

may be termed the petaloid facet (Fig. 5B). On enrollment these ridges are rotated (as shown on Fig. 6B) to become at right angles to those on the opposing doublure. On full enrollment, several pleurae are stacked vertically one above the other en echelon. With the ridges at right angles and resting cross-wise on one another a series of small passages remain openly in contact with the surrounding sea-water, even when the animal is tightly enrolled (Fig. 6C). A limited exchange of oxygenating water (arrows on Fig. 6C) will enable the trilobite to respire when enrolled - and hence permit it to remain in the enrolled state for longer. At the same time the sets of ridges bind together the stack of cuticular sheets of the pleural tips - another style of coaptation. Note that water passing between the ridges in the manner suggested reaches the inner edge of the doublure in the appropriate site to irrigate the exites (gill branches) near the dorsal surface of the pleurae.

During the enrolled state oxygen requirement is likely to have been low. To employ an appropriate analogy, some Recent aquatic isopods are able to live in suspended animation for months in an enrolled state provided a minimum respiration is possible (K. HaRRISON pers. comm. 1986). Certain spherically enrolling ("conglobating") marine isopods such as Dynamene actually have special openings which permit minimum respiration to continue while the animal is otherwise tightly enrolled. These openings are minute in proportion to the total body area of the animal, but are adequate for the purpose.

The relative orientation of the terrace ridges on the petaloid facets and its opposing doublure during enrollment has not been recorded previously. It is surely not coincidence. This is shown by the fact that the ridges on the anterior part of the thoracic doublure - that part in front of the vincular furrow unconnected with coaptation - have quite a different orientation from the posterior part and are much sparser (Fig. $5 \mathrm{E}$ ) than those opposing the petaloid facet. This distinction between anterior and posterior thoracic doublure is beautifully illustrated on Nileus by HAN (1984: pl. 3, fig. 10).

It is interesting to record that some trilobites which do not have petaloid thoracic facets have small, but well-protected "holes" between cephalon and pygidium during enrollment, which may also have permitted continued respiration in a different fashion (e. g. CAMPBELL 1977: text-fig. 22). 


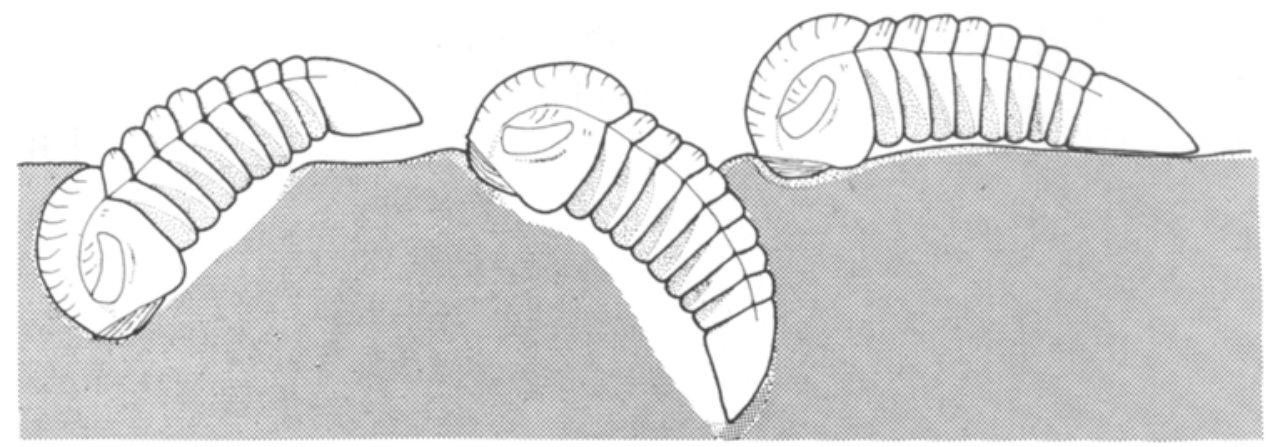

Fig. 7. Reconstruction showing three possible life postures of S. palpebrosus. Left, with cephalic burying assuming dorsal cephalic terrace ridges function in engagement with the sediment; centre, thoracic and pygidial burial leaving eyes in horizontal position - the bumastoid stance; right, attitude out of burrow.

Finally, at the top of each facet there are one or more ridges that do not follow the direction of those on the petaloid facet. Instead, these run transversely, parallel to the edge of the facet. When Symphysurus is fully enrolled these ridges alone project externally (Figs. 5B, 6), where they run closely along the adpressed edge of the facet. In such a specific position it is likely that these ridges were connected with detecting the state of enrollment. Similar ridges run along the cranidial rim in a position appropriate to detect completion of enrollment. Possibly there were minute sensillae associated with the ridges and running in series along the scarp slope. OsmólsKa (1975) and MrLLER (1975) have figured fine canals penetrating the cuticle in this position in sections through trilobite cuticle taken across terrace ridges. Setae between tergites, and functioning to assess their relative disposition, are commonly found on living malacostracans.

\subsection{Life posture and life habits}

Because almost all the specimens of $S$. palpebrosus are enrolled we have to infer the original posture of the trilobite in the extended state. The least enrolled specimen in the collections is shown on Fig. 1D, while Lu (1975: pl. 24, fig. 7) has figures a lateral view of a slightly distorted specimen in a more incompletely enrolled position. Note that the relatively great (sag.) cephalic convexity shows that the cephalon hangs down slightly below the level of the thorax and pygidium on Lu's figure. Nileids with lower cephalic convexity, such as Nileus itself (SCHRANK 1972: pl. 10, fig. 1b), have cephalon, thorax and pygidium more or less co-planar when extended.

The following morphological features are considered to be of particular importance in deducing posture:

1. S. palpebrosus has the peculiarity of its dorsal terrace ridges being confined to glabella and palpebral lobes, and variably along the thoracic axis, and never on the pleural flanks or on the pygidium. These terrace ridges are particularly strong on the glabella where the steep slopes face inwards and/or backwards.

2. Strongest terrace ridges of all lie on the doublure along the mid part of the cephalon; here the terraced ridges face outwards and upwards. 
3. The hypostoma does not lie parallel with the cephalic margin (as in other nileids), but is attached at the inner edge of the doublure parallel with the eyes on the dorsal surface, which means that it slopes upwards relative to the cephalic perimeter. Its terrace ridges have steep slopes facing forwards (Fig. 3).

4. With the eye in the horizontal position, which, according to CLARKSON $(1966,1969)$ is the most favourable position for a complete field of view, the thorax is not extended horizontally, but rather inclined downwards (e. g. Fig. 10C, LU 1975: pl. 10, fig. 1b). The precise angle of downward inclination is difficult to determine from largely enrolled specimens, and may have been variable within the species, but specimens such as that on Fig. $10 \mathrm{C}$ in which the anterior thoracic half ring is concealed beneath the posterior margin of the glabella suggests that the angle exceeded 40 degrees.

With these morphological features in mind several hypotheses of the relationships of the entire animal to the sediment surface can now be examined for plausibility (Fig. 7).

\section{Cephalic burying}

Especially in the German literature there has been much discussion about the functional aspects of cuticular terraces in living and fossil arthropods e. g. SEILACHER (1976), JEFFERIES \& LEwIS (1978), SAVAZzI $(1981,1982)$ and SCHmalfuss $(1978,1981)$. These structures have been interpreted as burrowing sculptures, and SCHMALFUSS (1981) interpreted such structures on the dorsal surface of trilobites as having an analogous function, while those on the doublure were interpreted as consolidating the sediment walls of a filter chamber beneath the animal. In any case a strong association with sediment was implicated by the occurrence of such terraces.

Terrace ridges on the cephalic exterior surface are well developed in Symphysurus, but limited largely to glabella and doublure; a cross section in cartoon version is shown on Fig. 8. If these terrace ridges were involved with engagement with the sediment (i. e. that part of the trilobite with prominent exterior terraces the buried portion) this would result in the stance shown in Fig. 7 (left), with the cephalic region buried, and part of the thorax, and the pygidium exposed. Once buried in this position the ridges would oppose any upward and outward movement from the sediment, for example acting in opposition to a moment produced by the thoracic appendages, in the direction shown by the arrow on Fig. 8.

However, detailed consideration of the functional aspects of this orientation poses several questions:

(a) How could Symphysurus manage to bury its cephalon in this position? The ratchet shaped terrace ridges have facing directions which are diametrically opposed at the inner (hypostomal) end and the dorsal (rear glabellar) end. Any direct downward movement into the sediment which favoured the one would be opposed by the other. The broad cephalic front is poorly shaped to push into the sediment by main force, and may be contrasted with trilobites with spatulate anterior margins which have been plausibly argued as forward burrowers (see HammanN 1983). The only burying movement consistent with the orientation of the ribs would be one in which the sediment engaged with the hypostome first, and then proceeded downwards around the mid-line of the cephalon in the direction of the arrow on Fig. 8 (see Fig. 9). But the hypostome is positioned inside the cephalon; hence any engagement with the sediment without burying the thoracic flanks (on which the terraces are absent) would entail an upward, or dorsal flexure of the thorax at the posterior end of the cephalon, which is both opposite to the attitude of thorax to cephalon found on real specimens, and futhermore incompatible with the articulation between cephalon and thorax. It could not work this way.

(b) The cephalic burying position inevitably involves burying other parts of the exoskeleton, including gena and the forward part of the thoracic pleurae, which are parts of the trilo- 


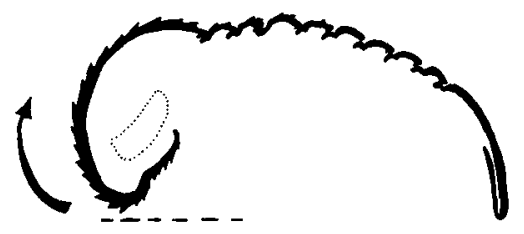

Fig. 8. Cartoon section along the length of S. palpebrosus showing the facing directions of the terrace ridges and the attitude of the hypostome within the cephalon. Scale of terrace ridges greatly enlarged. Dotted line marks lower edge of free cheeks showing elevation of inner edge of hypostoma.

bite more or less lacking terrace ridges on the exterior surface. If they functioned in the way described above it is difficult to explain their absence on these parts of the exoskeleton also supposedly involved in the burial process.

(c) Buried in this fashion, the well-developed eyes and the median tubercle are also deeply buried and could not function, which seems curious. If buried for protection, the thorax and pygidium without terraces presumably still protruded from the sediment, which is not useful. In short, the trilobite would be emulating the example of the apocryphal ostrich - burying its head in the mud.

I find these objections to cephalic burying posture compelling. Even if head burying were an exceptional act - done only at the time prey were caught, for example - the other morphological features of the exoskeleton do not seem to provide a propitious combination for digging downwards. Other possibilites have to be considered.

\section{Thoracic and pygidial burial}

The converse of the cephalic burying stance for Symphysurus discussed above is one in which those parts of the trilobite lacking terrace ridges are buried; this would mean that the pygidium and much of the thorax would be buried in the sediment, with the cephalon and part of the thoracic axis projecting (Fig. 7, centre). In this orientation the sediment would approximately come up to the anterior cephalic rim; the cephalic doublure with its strong ridges, and the hypostome, would be in contact with the sediment, but the dorsal ridges would not be.

This orientation results in the eyes being orientated in the "optimum" (CLARKSON 1969) horizontal position for maximum field of view. Furthermore, the orientation of the hypostome parallel to the eyes, as described above, becomes more explicable because in this orientation it would come to rest horizontally on the sediment. The downward-inclined thorax, which appears to be the real attitude (LU 1975), is then easily accomodated in the suggested posture. The strong terrace ridges on the cephalic doublure and hypostoma, would then be the ones implicated in retaining the sediment, in the manner discussed by ScHMaLFuss (1981).

Unusual though it might seem, this attitude is in fact well known in trilobites. It was discussed by BERGSTROM (1973) in illaenids (see also WHITTINGTON (1964: fig. 1b), and in more detail in Bumastoides and at least six more genera by WESTROP (1973); for convenience it is referred to here as the bumastoid stance. WESTROP showed the bumastoid stance persisted from the Upper Cambrian to at least the Silurian, characteristically among trilobites with high cephalic convexity and illaenid-like morphology. The presumed infaunal habit was polyphyletically derived. Symphysurus is the only nileid trilobite known to me which might be a candidate for this habit.

Like Symphysurus, trilobites having the bumastoid stance have exceptionally convex (sag.) cephalic shields, which tend to be deeper dorsoventrally than the thorax and pygidium. Again as in the case of Symphysurus, with the attitude of the eye horizontal the thorax and pygidium are downward sloping. Although not noted by WESTROP (1983), it also seems likely that the 


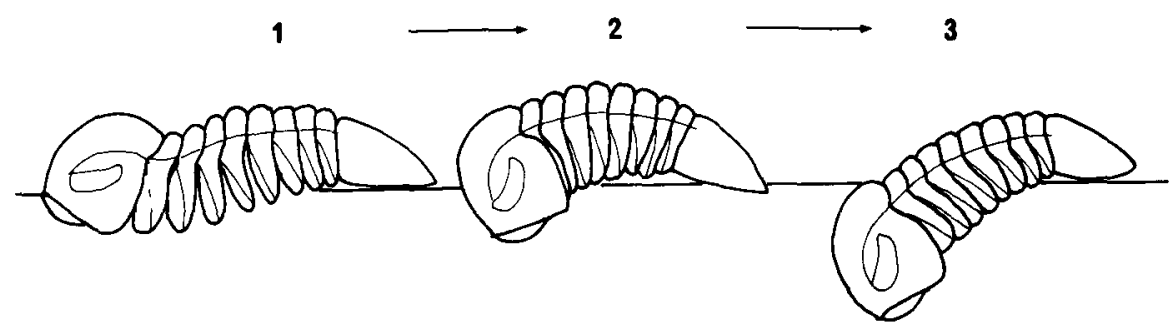

Fig. 9. Series of movements necessary for cephalic burying, taking into account the facing directions of the terrace ridges on ventral and dorsal surfaces and the attitude of the hypostoma. The trilobite has to engage the posterior end of the hypostoma first (left) and progressively dig downwards and forwards following the facing direction of the steep slopes of the terrace ridges. The smooth thorax and pygidium is not buried. The necessary steep flexure at the occiput renders this sequence unlikely; see text.

attitude of the hypostome described here (tucked inside cephalon, and curved away from exterior facing doublure) may also have applied to other species with the bumastoid stance for example the hypostome of Illaenus is described in that attitude by JAANUSSON (1954), and I have observed it on several illaenids and bumastids. Interestingly, most of the forms cited by Westrop also have a median cephalic tubercle of the ocellar type. The specimen of S. palpebrosus on Fig. 10C most closely corresponds to this supposed life orientation.

I prefer the bumastoid stance as an explanation of the morphology of S. palpebrosus, both because it seems to be more plausible from the point of view of the constructional morphology, and by comparison with other trilobites with similar adaptations, some of which are claimed to have been recovered in life position.

Acceptance of this orientation means, however, that the part of the dorsal surface of the exoskeleton with terrace ridges is not the part that was dug into the sediment. Instead, the smooth part of the pygidium and the flanks of the thorax was presumably capable of digging
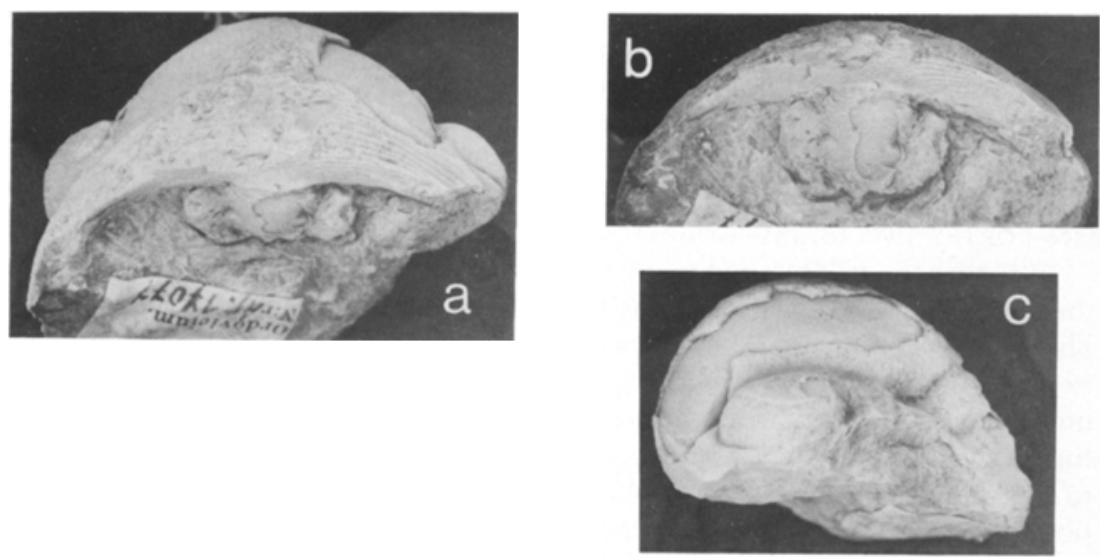

Fig. 10. Attitude of hypostoma of S. palpebrosus, Ar 17077, $\times 1.5$, specimen with hypostoma attached (Fig. b); a, anteroventral view showing hypostome inside cephalon parallel to eyes, with broad swathe of forward-facing doublure $\mathrm{c}$, lateral view showing eye horizontal, and corresponding thoracic orientation with downsloping angle as required by bumastoid stance - note: hypostome also horizontal in this attitude. 
backwards rapidly into the mud. The same may have been true of bumastids (e. g. WESTROP 1983: fig. 2a). It follows that the terrace ridges on the cephalon had some other function. It is interesting to note that ridges are largely absent on the free cheeks - probably at least partly buried on the bumastoid stance hypothesis - but are present on the first few thoracic axial rings, which may have been exposed. In summary, the disposition of the ridges is consistent with the bumastoid stance, but necessitates some explanation for their function other than engagement with the sediment. However, those strong ridges on the cephalic doublure are orientated correctly to have an appropriate effect on stabilising the edge of the burrow.

There is no necessity to adopt a "ridge" paradigm for burrowing. For example, although many burrowing bivalves do have such ridges, others, such as Nuculanidae and the razor shells Ensis and Solen, do not. In such clams the exterior of the shell is polished rather than ribbed. The burrowing bivalve Donax (see ANSELL 1985) is capable of extremely fast burrowing, but the actively burrowing margin of the shell is smooth, and it is the trailing edge of some species on which there are terrace ridges. The smooth posterior parts of Symphysurus may be regarded in an analogous way. In Sweden the associated lithology is a fine-grained limestone, apparently with few larger grains other than comminuted shell fragments (muddy lithologies are associated with French and Bohemian species of the genus also). Terrace ridges as burrowing aids may have been more effective in sand-grade sediments (cf. SEILACHER 1976).

\section{Free living}

WESTROP (1983) favoured the view that trilobites having the bumastoid stance were suspension feeding in situ in their burrows. However, it is true that of the dozens of specimens of $S$. palpebrosus in the Naturhistoriska Riksmuseet in Stockholm, and those I have seen elswhere, almost every one is enrolled to some extent, and most are tightly so. Illaenids, too, are frequently collected in an enrolled condition. In the bumastoid stance, with the posterior part of the trilobite buried, it is difficult to see how enrollment could be achieved. Given the sophisticated coaptative devices of Symphysurus described above it is scarcely possible to dismiss enrollment as fortuitous, only happening to a few individuals "caught out" of their burrows. Sections show that the dorsal cuticle is also of equal thickness along the length of the trilobite, so that its strength in the enrolled state is maximised, whereas the pygidial doublure is half as thick; with the posterior of the animal customarily buried we might have expected a diminution in thickness along the length of the exoskeleton instead of an abrupt change in thickness at the pygidial margin. It seems likely that $S$. palpebrosus spent at least part of its life as a member of the vagrant benthos. I do not consider it likely to have been a fast, active swimmer, because its poorly streamlined shape is unlike that of trilobites adapted for this mode of life (see FORTEY 1985 for discussion).

Whether the trilobite fed while free living, and under what circumstances it retreated to the bumastoid stance, are questions which it is not possible to solve objectively from the morphology alone. Note that the very wide doublure, which is closely reflexed against the dorsal exoskeleton on both thorax and pygidium, and which closely approaches the axis at which the limbs were articulated, rules out the possibility of the doublure as a sediment-gripping structure in the manner shown by SCHMALFUSS (1981) if the limbs are going to have space enough to operate (FORTEY 1985). The cephalic doublure alone has the right orientation for this function. It is perhaps worthwhile to speculate briefly on how Symphysurus could have fed while on the sediment surface in the orientation shown on Fig. 7 (right). The eyes in this position would have been tilted slightly forwards and the field of view would have been shifted anteriorly compared with that shown for Nileus by FORTEY \& CLARKSON (1975). The hypostoma, which parallels the eye, would then be upward-tilted, within the cephalic cavity. If, as usually assumed, the mouth were at the posterior end of the hypostoma, it would have been raised 

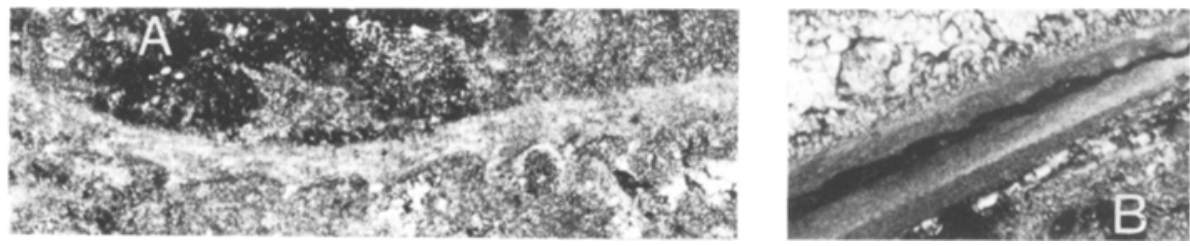

Fig. 11. Photographs of sections through cuticle of $S$. palpebrosus specimen taken from cellulose acetate peels of polished surfaces, $\times 10$. a, hypostoma preserved inside enrolled specimen to show sharp crests of terrace ridges in unabraded condition; $b$, opposing surfaces of facet and thoracic doublure in enrolled state showing gap between produced by arrangement of terrace ridges (cf. Fig. 6c).

clear of the sediment surface: hence direct ingestion of sediment would not have been possible. However, this hypostomal attitude would create a broad chamber beneath the cephalon (Figs. 8, 10), embraced by the cheeks on either side with their reflexed doublure. This chamber could have been utilised for suspension feeding: particles raised into suspension by the thoracic limbs passed forward to the cephalic chamber where they are sorted by the cephalic limbs for ingestion. Such a feeding mode is as plausible as the suspension feeding discussed in some detail by WESTROP (1983:21) who described the feeding in the bumastoid stance as achieved via "an open space ... maintained below the cephalon and at least the anterior part of the thorax" while the trilobite was in its burrow. If this were the case one might expect that the cephalon would have an anterior arch - as do many trilobites (e. g. calymenids, phacopids, some olenids) - to favour ingress of respiratory and feeding currents. This is not the case in Symphysurus, nor for that matter in illaenids having bumastoid stance. Hence it does seem plausible that feeding was achievable away from the burrowing attitude. To speculate further, there are living marine arthropods, such as Nephrops, which feed nocturnally and retreat into burrows by day. If Symphysurus had such habits it might explain the apparent paradox of the inferred burrowing habits allied with the common occurrence of enrolled specimens, and the sophisticated coaptative devices. The very large eyes with minute lenses may have been adapted to function at very low light intensities.

\subsection{Summary of function of terrace ridges}

In view of the interest in cuticular ridges in arthropods it is worthwhile summarising the conclusions about their function in Symphysurus palpebrosus. A simple and invariable relationships to burrowing in sediment is not possible to defend given the siting of the terraces on the trilobite, and the constraints imposed by the rest of the exoskeleton. Of course most of the terrace ridges on the surface of specimens are somewhat abraded, but a section (Fig. 11) through the hypostome inside an enrolled specimen shows how sharp the crests of the ridges were.

1. On the pleurae terrace ridges are confined to the petaloid facets, which during enrollment telescoped beneath the thoracic doublure of the preceding segment. The criss-cross arrangement of these ridges during enrollment suggests that they functioned to allow a low level of respiration to continue while the trilobite was securely locked in its protective attitude (for which there are Recent analogues), without loss of adherence between stacked pleural tips in the enrolled state. Also, in the enrolled condition the doublure of the cephalon and that of the pygidium become adpressed; engagement of parallel sets of terrace ridges on the cephalic doublure with finer ones on the pygidial doublure probably served to enhance the coaptation by resisting sliding or twisting between the doublural surfaces. 


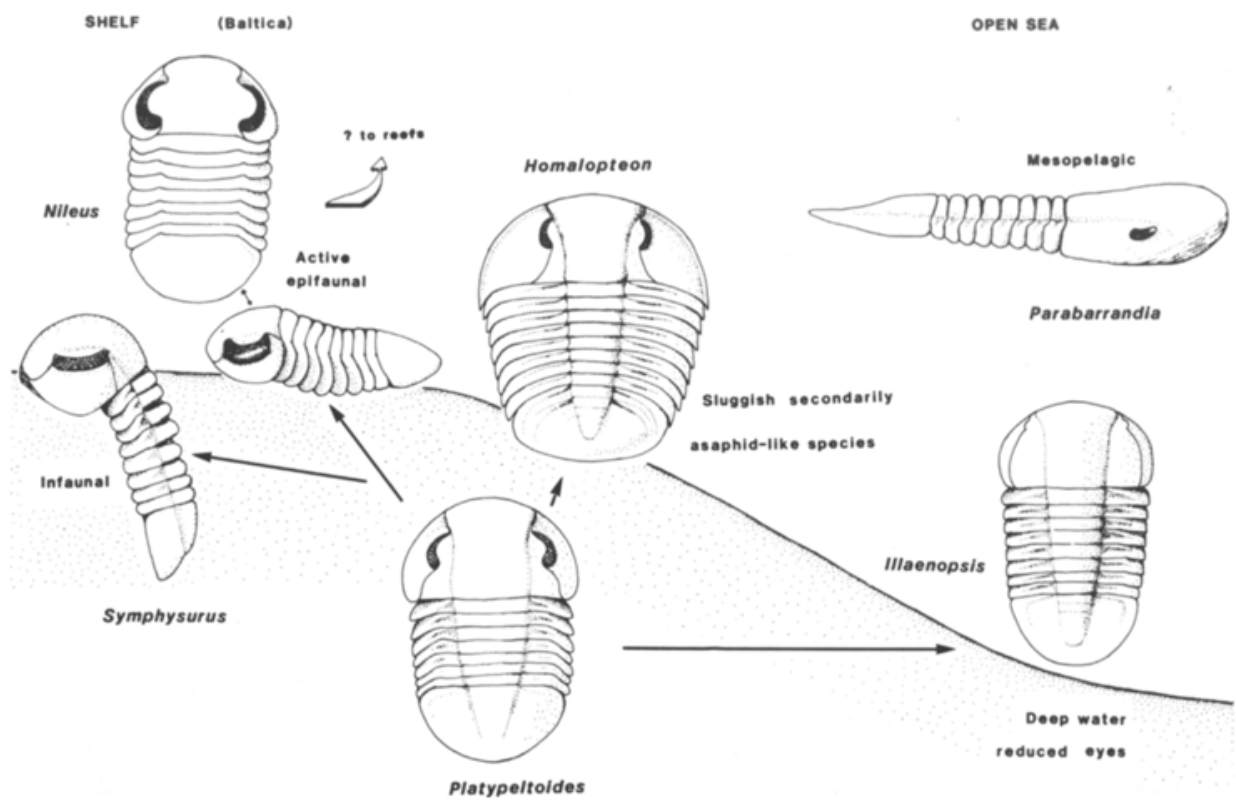

Fig. 12. Scenario of different life habits within the trilobite family Nileidae; Symphysurus is the only likely candidate for infaunal habits. Adoption of the bumastoid stance in other families is a parallelism.

Long ridges on the edge of the petaloid facets were placed in such a position that they were likely associated with monitoring the state of enrollment.

2. Terrace ridges on the front of the cephalic doublure, where they are strongest over the entire exoskeleton, and over the middle body of the hypostoma, are placed in the correct position to stabilise the front edge of the burrow when the trilobite dug into the sediment in the bumastoid stance. If the trilobite burrowed backwards as suggested in this paper these ridges are orientated correctly to slide in easily during burial, because their steep slopes face forwards, and to stabilise the burrow once emplaced.

3. Terrace ridges on the dorsal cephalic surface, and the thoracic rings, correspond in distribution closely with those parts of the exoskeleton which were not concealed during burial. The coincidence of these sets of terraces with the inferred burial position deduced from other morphological features is remarkable. If the objections (based on the rest of the morphology) given above to cephalic burial are correct, then these ridges can not have had a function connected with engagement with the sediment, nor of course with enrollment. Some other function must be sought. MILLER (1975) made a case for terrace ridge system as a "current monitoring" apparatus. In their position above the sediment surface the ridges on Symphysurus would be appropriately placed to monitor currents, and one might surmise that the animal needed to do so to receive sensory information, or, if it fed in its burrow as thought by WESTROP (1983), to optimise its position relative to oxygenating or nutrient bearing currents. Plausible though such explanations are they belong in that category of inference about the mode of life of extinct animals for which there is no independent method of testing. Other explanations of terrace ridge function could be suggested (e. g. camouflage? sexual recognition? protection against epifaunal settling?) which might also be plausible. There is no method of deciding between one or another, or some combination of ef- 
fects, other than the predilections of the author. I prefer to leave the function of these dorsal terraces as an open question.

In conclusion, it is clear that cuticular terrace ridges were able to perform several different functions in the life of the trilobite; some of these are identified with reasonable certainty; engagement with the sediment was only one of these functions.

\section{Life habits of Symphysurus compared with other nileid trilobites}

Finally, as a postscript to the detailed consideration of the functional morphology of one species, $S$. palpebrosus, it is worthwhile placing this form within the wider context of its relatives. The family Nileidae is not an unusually diverse group of Ordovician trilobites, yet within this group a number of different life habits pertained (Fig. 12). There is no opportunity here to rehearse the lines of argument for the life habits of other nileids; some have been discussed elsewhere (Parabarrandia, FORTEY 1985; Illaenopsis, FORTEY \& OwENS 1986). The main point is that backward burrowing was one of a number of life habits which could be acquired within a monophyletic group. The primitive nileid morphology represented by Platypeltoides in the early Tremadoc was capable of modification to a specialised combination of derived characters, involving changes to cephalic proportions, hypostomal attitude, eye orientation and vincular structures, as characterising $S$. palpebrosus by the end of the Arenig, a time interval of about $15-20 \mathrm{~m} \mathrm{y}$. On this time scale, there is no reason why other trilobite families should not have produced species capable of the bumastoid stance, which lends credence to the notion (e. g. WESTROP 1983) that it is likely to have been derived polyphyletically.

\section{Literature}

ANGelin, N. P. (1851): Palaeontologia Svecica. Part 1, Crustacea Formationis Transitionis. Fasc. 1: 1-20, pls 1-24; Lund.

- (1854): Palaeontologia Scandinavica. Part 1, Crustacea Formationis Transitionis. Fasc. 2: 21-92, pls 25-41; Lund.

ANSELL, A. D. (1985): Species of Donax from Hong Kong: morphology, distribution, behaviour and metabolism. [In:] MORTON, B. \& DudGeON, D. (eds.): The Malacofauna of Hong Kong and southern China, 2: 19-48; Hong Kong.

Balashova, E. A. (1961): Some Tremadoc trilobites of the Aktyubinsk region. - Trud. Geol. Inst. Leningrad, 18: 102-144, pls 1-4; Moscow. [In Russian]

BARRANDE, J. (1852): Systeme Silurien du centre de la Bohème. 1ère partie, 1-935, 51 pls; Prague und Paris.

BednarczyK, W. (1968): The Ordovician in the region of Ketrzyn (NE Poland). - Acta Geol. Polon., 18: 707-49, 4 pls; Warsaw.

BERGSTRÖM, J. (1973): Organisation, Life and Systematics of trilobites. - Fossils Strata, 2: 1-69, 5 pls; Oslo.

BoECK, C. (1838): Übersicht der bisher in Norwegen gefundenen Formen der Trilobiten-Familie. - Gaea Norvegica, H. 1: 138-45; Oslo (Kristiania).

BRøGGER, W.C. (1882): Die silurischen Etagen 2 und 3 im Kristianiagebiet und auf Eker, ihre Gliederung, Fossilien, Schichtenstörungen und Kontaktmetamorfosen. 1-376, 12 pl.; Oslo.

Burmeister, H. (1843): Die Organisation der Trilobiten aus ihren lebenden Verwandten entwickelt nebst einer systematischen Übersicht aller zeither beschriebenen Arten. 1-147, 6 pls; Berlin.

- H. (1846): The organisation of trilobites, deduced from their living affinities, with a systematic review of the species hitherto described. 1-136, 6 pls; Ray Society, London. [Translation, with updating, of 1843]

CAmpBeLL, K. S. W. (1977): Trilobites of the Haragan, Bois d'Arc and Frisco Formations (Early Devonian) Arbuckle Mountains Region, Oklahoma. - Bull. Okla. Geol. Surv., 123: 1-139, 40 pls; Norman, Okla.

Chang, W.-T. \& Fan, C.-S. (1960): Trilobites of the Ordovician and Silurian Periods of the Ch'i-Lien Mountains. - [In:] Geological gazeteer of the Ch'i-Lien Mountains, 83-147, 10 pls; Beijing. 
Clarkson, E. N. K. (1966): The life attitude of the Silurian trilobite Phacops musheni Salter, 1864. - Scot. J. Geol., 2: 76-83; Glasgow.

- (1969): A functional study of the Silurian odontopleurid trilobite Leonaspis deflexa (LAKE). - Lethaia, 2: 329-44; Oslo.

Cocks, L. R. M. \& ForTey, R. A. (1982): Faunal evidence for oceanic separations in the Lower Palaeozoic of Britain. - J. geol. Soc. London, 139: 467-80; Oxford.

Courtessole, R. \& Pillet, J. (1975): Contribution à l'étude des faunes trilobitiques de l'Ordovicien de la Montagne Noire: les Eulominae et les Nileidae. - Ann. Soc. géol. Nord., 95: 251-272, pls 24-27; Lille.

Dalman, J. W. (1827): Om palaeaderna eller sa kallade Trilobiterna. - Kongl. Svenska Vet. Akad Handl. for $1826,113-152,6$ pls.

Dean, W. T. (1971): The Lower Palaeozoic stratigraphy and faunas of the Taurus Mountains near Beysehir, Turkey. 2. The trilobites of the Seydisehir Formation (Ordovician). - Bull. Brit. Mus. nat. hist. Geol., 20: 1-24, 5 pls; London.

- (1973): The Lower Palaeozoic of the Taurus Mountains near Beysehir, Turkey. 3. The trilobites of the Sobova Formation (lower Ordovician). - Bull. Brit. Mus. nat. hist. Geol,, 24: 279-378, 12 pls; London.

FORTEY, R. A. (1975): The Ordovician trilobites of Spitsbergen. 2. Asaphidae, Nileidae. Raphiophoridae and Telephinidae of the Valhallfonna Formation. - Skr. Norsk Polarinst., 162: 1-125, 41 pls.

- (1985): Pelagic trilobites as an example of deducing the life habits of extinct arthropods. - Trans. Roy. Soc. Edinb., 76: 219-230; Edinburgh.

Fortey, R. A. \& Clarkson, E. N. K. (1976): The function of the glabellar "tubercle" in nileid and other trilobites. - Lethaia, 9: 101-6, 4 figs.

Fortey, R. A. \& OwENs, R. M. (1978): Early Ordovician (Arenig) stratigraphy and faunas of the Carmarthen district, south-west Wales. - Bull. Brit. Mus. nat. hist. Geol., 30: 225-294, 12 figs, 11 pls; London.

- (1987): The Arenig Series in South Wales. - Bull. Brit. Mus. nat. hist. Geol. 41. [in press]

GoldFuss, A. (1843): Systematische Übersicht der Trilobiten und Beschreibung einiger neuer Arten derselben. - N. Jb. Min. Geogn. Geol. Petrefakten-Kunde, 1843: 537-67, pls 4-6; Stuttgart.

Hammann, W. (1983): Calymenacea (Trilobita) aus dem Ordovizium von Spanien: ihre Biostratigraphie, Ökologie und Systematik. - Abh. senckenberg. naturforsch. Ges., 524: 1-126, 25 pls; Frankfurt a. M.

- (1985): Life habit and enrolment in Calymenacea (Trilobita) and their significance for classification. - Trans. Roy. Soc. Edinb., 76: 307-18.

HAN, N.-R. (1984): The panderian organs of Nileus nileonis (Trilobita). - Acta Palaeont. Sinica, 23: 513-8, 3 pls; Beijin.

Henry, J.-L. (1980): Trilobites ordoviciens du Massif Armoricain. - Mém. Soc. Géol. Mineral. Bretagne, 22: $1-250,95$ figs, 48 pls; Rennes.

- (1985): New information on the coaptative devices in the Ordovician trilobites Placoparia and Crozonaspis and its significance for their classification and phylogeny, - Trans. Roy. Soc. Edinb., 76: 319-24; Edinburgh.

Holub, K. (1911): Über eine neue Fauna des Untersilurs in der Umgebung von Rokycan.- Bull. internat. Acad. Sci. Boh., 16: 20-23, 2 pls; Praha.

JAAnusson, V. (1954): Zur Morphologie und Taxonomie der Illaeniden. - Ark. Miner. Geol., 1: 545-83; Stockholm.

JAANUSSON, V. \& Bergstróm, S. M. (1980): Middle Ordovician faunal spatial differentiation in Baltoscandia and the Appalachians. - Alcheringa, 4: 89-110; Sydney.

Jefferies, R. P. S. \& Lewis, D. N. (1978): The English Silurian fossil Placocystites forbesianus and the ancestry of the vertebrates. - Phil. Trans. Roy. Soc. London Ser. B, 282: 205-323, 35 figs. 15 pls; London.

JohansSON, H. G.; KARIS, L. \& KJELISTROM, G. (1972): Notes on a new locality at Ljungsbro in the lower Ordovician of Östergotland, southern Sweden. - Geol. For. Stockh. Forh., 94: 578-80; Stockholm

LAKE, P. (1942): A monograph of the British Cambrian trilobies. Part 13. - Palaeontograph. Soc. (Monogr.): 307-332, pls 44-6; London.

LINDSTRÖM, G. (1901): Researches on the visual organs of trilobites. - Kongl. Svenska Vet.- Akad. Handl. 34: 1-86, 6 pls; Stockholm

Lisogor, K. A. (1961): Tremadoc trilobites from the Kendyktas region. - Trud. Geol. Inst. Leningrad 18: 55-91, 4 pls.; Moscow [in Russian]

Lu, Y.-H. (1975): Ordovician trilobite faunas of central and southwestern China. - Palaeontologia Sinica (B) 152: 1-463; 48 figs, 50 pl.; Beijing. [in Chinese, English summary]

MrlleR, J. (1975): Structure and function of trilobite terrace lines. - Fossils Strata 4: 155-78, 21 figs; Oslo ModlinsKi, Z. (1973): Stratygrafia i rozwoj ordowicku w polnocno-wschodniej polsce. - Pr. Inst. Geol., 72: 1-74, 10 figs, 5 pls; Warsaw. [in Polish] 
MOdLINSKi, Z. \& Pokorski, J. (1969): Stratigraphy of the Ordovician in borehole Jezioro Okragte. Kwart. Geol., 13: 777-793, 8 pls; Warsaw.

Moore, R. C. (ed.) (1959): Treatise on Invertebrate Paleontology, Part O, Trilobita. 1-560, 415 figs; Geol. Soc. America and Univ. Kansas Press.

Neben, W. \& Krueger, H. H. (1971): Fossilien Ordovizischer Geschiebe. - Staringia, 1: 50 pls; Oldenzaal (Holland).

OsmósSKA, H. (1975): Fine morphological characters of some Upper Palaeozoic trilobites. - Fossils Strata, 4: 201-8; Oslo.

POULSEN, V. (1965): An early Ordovician trilobite fauna from Bornholm. - Meddr. Dansk geol. Foren., 16: 49-113, pls 1-9; Copenhagen.

- (1966): Cambro-Silurian stratigraphy of Bornholm. - Meddr. Dansk geol. Foren., 16: 117-137; Copenhagen.

SAVAzZI, E. (1981): Functional morphology of the cuticular terraces in Ranina (Lophoranina) (brachyuran decapods: Eocene of Italy). - N. Jb. Geol. Paläont. Abh., 162: 231-243; Stuttgart.

- (1982): Burrowing habits and cuticular sculptures in Recent sand-dwelling brachyuran decapods from the Northern Adriatic Sea (Mediterranean). - N. Jb.- Geol. Paläont. Abh., 163: 396-88; Stuttgart.

Schmalfuss, H. (1978): Structure, patterns and function of cuticular terraces in Recent and fossil arthropods. - Zoomorphologie, 90: 19-40, 33 figs.

- (1981): Structure, patterns and function of cuticular terraces in trilobites. - Lethaia, 14: 331-41; Oslo.

Schrank, E. (1972): Nileus-Arten (Trilobita) aus Geschieben des Tremadoc bis tieferen Caradoc. - Ber. dt. Ges. geol. Wiss. ser. A, 17: 351-75, 11 pls; Berlin.

SeIlacher, A. (1976): Panzerskulpturen bei Arthropoden. Terrasslinien des anomuren Krebses Emerita. Zbl. Geol. Paläont, 1976: 313-4. Stuttgart.

STøRMER, L. (1940): Early descriptions of Norwegian trilobites. The type specimens of C. BOECK, M. SARS and M. EsmarK. - Skr. norske Vid.-Akad. 1. nat.-mat. Kl. 20: 113-51, 3 pls.; Oslo.

TJERNVIK, T. (1956): On the early Ordovician of Sweden: stratigraphy and fauna. - Bull. geol. Instn. Univ. Uppsala, 36: 107-284, 11 pls.; Uppsala.

Westrop, S. (1983): The life habits of the Ordovician illaenine trilobite Bumastoides. - Lethaia, 16: 15-24, 4 figs.; Oslo.

Whittington, H. B. (1964): Taxonomic basis of paleocology. [In:] Imbrie, J. \& Newell, N. D. (eds): Approaches to Paleoecology: 19-27; New York (Wiley).

- (1965): Trilobites of the Ordovician Table Head Formation, western Newfoundland. - Bull. Mus. comp. Zool. Harv., 132: 275-442, 68 pls; Cambridge, Mass.

Eingang des Manuskripts bei der Schriftleitung am 24. 3. 1986. 